\title{
Early villages and prehistoric sites in the Abharroud Basin, northwest of the Iranian Central Plateau
}

\author{
Sajjad Alibaigi ${ }^{1}$, Shokouh Khosravi ${ }^{2}$ and Abolfazl Aali 3 \\ 1 Department of Archaeology, University of Tehran, Tehran, IR; sadjadalibaigi@gmail.com \\ 2 Department of Archaeology, University of Tarbiat Modares, Tehran, IR; shokouh.khosravi@gmail.com \\ 3 The Archaeological Museum of Zanjan, Zanjan; aaliabolfazl@yahoo.com
}

\begin{abstract}
The Abharroud basin is an important region in archaeological studies of the northwestern outskirts of the central plateau, and the west and northwest of Iran. Considering its environmental capabilities and geographical location, studying the region can leads us to a better understanding of regional relations and also inter-regional interaction between the cultural-geographical regions. During the two seasons of archaeological survey, 257 archaeological sites were discovered, dating from the lower Palaeolithic to recent ages. Of these, 34 sites contained prehistoric remains. Most of the identified sites are the remains of scattered villages and seasonal camps in different areas of the basin, on the plain and also impassable heights.
\end{abstract}

IZVLEČEK - Kotlina Abharroud je pomembna regija v arheoloških študijah severozahodnih obronkov osrednje planote ter zahodnega in severozahodnega Irana. Ob upoštevanju njenih okoljskih možnosti in geografske lege lahko s študijem te regije bolje razumemo kulturno-geografske odnose znotraj regije in med regijami. V dveh sezonah arheoloških terenskih pregledov smo odkrili 257 arheoloških najdišč, ki sodijo v čas od zgodnjega paleolitika do mlajših obdobij. 34 najdišč vsebuje prazgodovinske ostanke. Večina prepoznanih najdišč predstavlja ostanke vasi in sezonskih taborov, ki so razpršeni na različnih območjih kotline, tako v ravnini kot v težko dostopnem višavju.

KEY WORDS - survey; the Abharroud basin; settlement; prehistoric period

\section{Introduction}

Archaeological surveys were frequent in the western and especially in southwestern Iran, but unfortunately, we know only little about the past cultures of Zanjan province since no adequate attention has been paid to the cultural and historical remains of this province. Hence, there is very little information about the prehistoric cultures of the region. Considering that the region was attractive to various human groups at different times and the unique location of the region among three different cultural zones on the central plateau in western and northwestern Iran, the study of ancient settlements and the evaluation of their features seemed necessary. Thus, an archaeological project was carried out through two survey seasons in 2003 and 2005 in order to study and identify the archaeological sites of the Abharroud basin (Aali 2003a; 2003b; 2006a; $2006 b)$. The project, which was conducted by Abol- fazl Aali, provided valuable information about the region from very ancient times up to the present; this paper presents the settlement patterns of the prehistoric sites.

\section{The objectives of the survey}

Zanjan province, especially its eastern parts, has always attracted various human groups. The region is rich in natural resources necessary for habitation, such as fertile plains, permanent rivers, streams and springs, animal and plant resources, which makes it a popular area for occupation. The province is located between two mountain ranges to the north and south and the main transport route was always through the plains of Abhar and Khorram Darreh. As this region has been a natural and principal way to connect the central plateau with northwestern 
Iran since the Neolithic, the study of settlement through time is of great value. This region is also important because the road to Great Khorasan passes through it to the east. Therefore, studying the settlement patterns of the region can provide valuable information and a better understanding of the interaction between nearby cultural-geographical regions. The main objectives of the survey were: (i) to identify ancient sites; (ii) to investigate settlement patterns and their distribution in different periods; (iii) to draw an archaeological map of the settlements; (iv) to study inter and intra-site relations and the interaction with the environment in the region; and finally (v) to clarify the nature of relations with nearby regions.

\section{The survey method}

The Abharroud basin, which includes the towns of Abhar and Khoram Dareh, is a vast area of $3400 \mathrm{~km}^{2}$, of which $2993 \mathrm{~km}^{2}$ belongs to the town of Abhar and the remaining $407 \mathrm{~km}^{2}$ to the town Khoram Dareh. The first survey was carried out in an area of $1200 \mathrm{~km}^{2}$, which included the entire town of Khoram Dareh and some parts of Abhar. During the second season, the remaining parts of Abhar were covered, which included the districts of Sa'een Qaleh, Sonbol Abad, Sultanieh, Darsajin, and Dolat Abad (Aali 2006b.18). Considering the vastness of the area, existing limitations, preliminary knowledge about the conditions of the settlements in the region and its unique location, the region was intensively surveyed with vehicles and on foot. We carefully explored and studied wherever there was a possibility of occupation, such as caves, rock shelters, river banks, areas around springs and streams, valleys, mountainsides, drained river chambers, and seasonal flood areas. In order to have a better understanding of the region, we used maps with a scale of 1 : 50000 and GPS for geographical coordinates. We also enjoyed the help and guidance of local people to find sites, and we examined all the sites that villagers and shepherds informed us about, so that we could search all the sites with any potential. Having identified the sites, we surveyed them intensively, although surface materials were sampled randomly. To record preliminary data, we devised a form on which we recorded geographical information, the dimensions and area of sites, data on the sites (their position and situation, extent of human disturbance, etc.), and the quantity and distribution of cultural materials. We also drew a topographical map of each site to be attached to the corresponding archaeological data.

\section{Background to the archaeological research}

Few surveys have been carried out in this region since the beginnings of archaeology in Iran. Moreover, almost all archaeological surveys were concentrating on the Islamic era and no attention was paid to prehistoric times (for previous field research see: Aali 2006b). Archaeological surveys in the Abharroud basin began in the early 1350 's, with surveys and excavations in Sultanieh and studies of the remains of the Islamic era (Ganjavi 1974; 1976a; 1976b). Although archaeological studies was carried out in the region every now and then, no evidence was obtained on prehistoric cultures until recent years (Alibaigi, Khosravi 2007; 2009; Alibaigi et al. 2010; 2011; Alibaigi, Khosravi in press; Khosravi et al. 2009; 2010; Khosravi, Alibaigi 2008; in press; Masoumi 2008; Aali 2006b).

Unfortunately, the results of surveys and studies on the prehistory of the region, and even their preliminary reports, have not yet been published. Tapeh Noor, near Sultanieh, is the only prehistoric site, which has been excavated. Prehistoric trenches at the Nour Tapeh were excavated in the summer of 2004 by Parvin Kazempour Esmati, managed by Aliasghar Mirfattah and supervised by the Sultanieh Archaeological Project. There is also little information about the excavations of this important Chalcolithic site. The only information we have is based on personal meetings and a visit to the site during the excavation. In 2009, this site was excavated again by Kazempour Esmati in order to explore the stratigraphy (Kazempour Esmati 2009). Tepe Khaleseh, the only Neolithic settlement in the region, was also excavated in the summer of the same year by Hamidreza Valipour (Valipour et al. in press).

\section{Natural and geographical location}

In order to achieve a full understanding of prehistoric occupation conditions in the region, the geographical features must be taken into consideration. Abhar and Khorram Darreh (the Abharroud basin) are among seven towns in the Zanjan province and are located on its eastern border. The Qazvin province bounds Abhar to the east and south, the towns of Khodabande and Ijrud to the west, and the towns of Zanjan and Tarom to the north. The town of Khorram Darreh, with an area of $407 \mathrm{~km}^{2}$, is almost surrounded by the territory of Abhar, it neighbours to Tarom to the north and is surrounded by Abhar on its southern, eastern, and western borders (Map. 1). Khorram Darreh, as the province capital, is located 
$80 \mathrm{~km}$ from Zanjan and $95 \mathrm{~km}$ from Qazvin; it lies $1570 \mathrm{~m}$ above sea level (Sazman-e Modiriat va barnamehrizi ostan-e Zanjan 2005.20).

The Abharroud basin is one of the inlets of a salt lake and also a main sub-basin in the centre of the Iranian plateau, which is comprised of two large tributaries, one permanent and the other seasonal. The Abharroud basin, including the plains and valleys of the towns of Abhar and Khorram Darreh, extends from

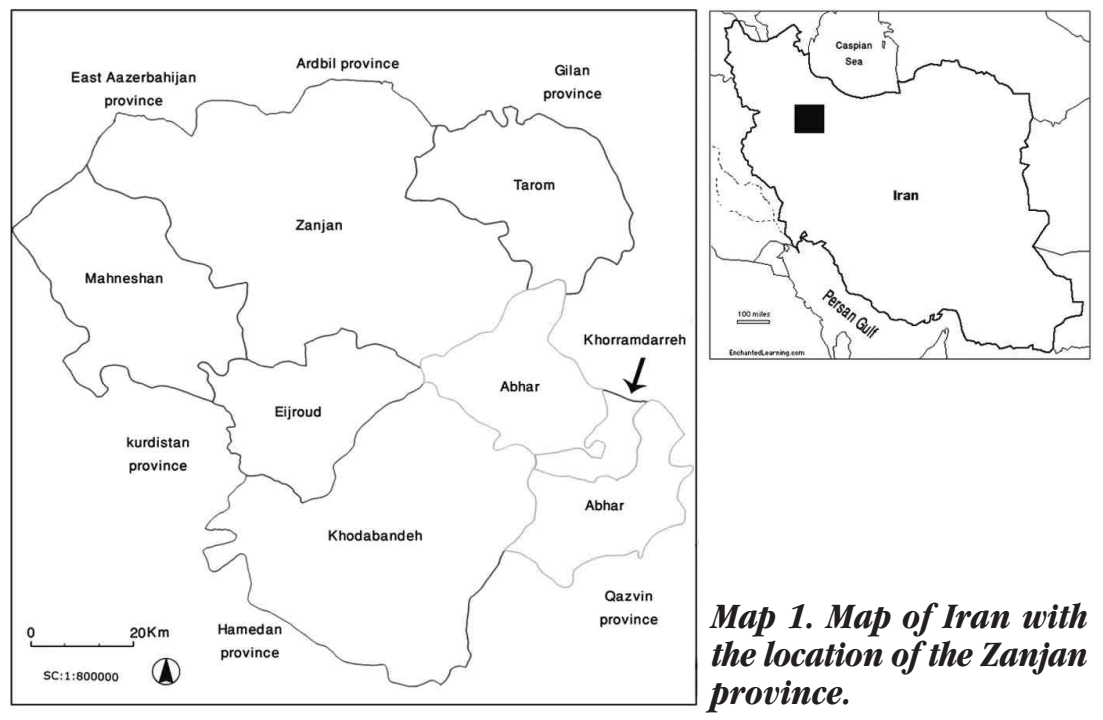
eastern longitude of $48^{\circ} 48^{\prime}$ to $49^{\circ} 30^{\prime}$ and from the northern latitude of $35^{\circ} 57^{\prime}$ to $36^{\circ} 36^{\prime}$, in eastern Zanjan. This basin borders the Qezel Ozan basin to the north, the Kharrud river to the south and the Zanjanrud river to the east. The basin includes a highland region on the western part of the Alborz mountain range and on its southern mountainside between two high mountain ranges running east to west (Map 2). The basin covers the area of $c .2300 \mathrm{~km}^{2}$, with $900 \mathrm{~km}^{2}$ belonging to plains. The mountains in the Abharroud basin are formed in two parallel mountain ranges extending northwest-southeast as a continuation of the Zanjan Mountains from the Mt. Qaflankouh to the plain of Qazvin (Takestan). These mountains are connected to the Alborz mountain ranges to the north and to the Zagros mountain ranges to the south and southwest. The rain and snow, which falls in these mountains, form the various tributaries of the Abharroud, which leave large deposits in the valley and create fertile land for farming. The vegetation in the highlands and mountains makes pastoral activities possible, which in turn led to the development of human societies and economic centres such as Sultanieh, Saeen Qaleh, Heidaj, Khorram Darreh, Abhar, and numerous villages ( $\mathrm{Saz}$ man-e Amozesh va Parvaresh ostan-e Zanjan 1996. 10). The highest point in the basin is the Sendandagh peak, which is $2975 \mathrm{~m}$ above sea level, while the lowest point is the confluence of the Abharroud and Kharrud rivers at a height of $1250 \mathrm{~m}$ above sea level. The width of the plain between the two mountain ranges is $17 \mathrm{~km}$ at its widest; it is covered with quaternary deposits.

The rivers in this basin mostly rise in the western and central mountains of the Alborz. The Abharroud has two tributaries, one of which is seasonal and the other permanent. One of these tributaries runs from Chaman Sultanieh and the other from the mountains south of Kinehvars. The Abharroud is $60 \mathrm{~km}$ long and the total length of its branches is $c$. $400 \mathrm{~km}$.

The climate is semi-arid with very cold winters. The area we studied does not enjoy good vegetation due to the environmental features. The region has steppe vegetation in the form of shrubs. Low areas of the region are almost entirely devoid of vegetation and the vegetation in higher areas includes shrubs and grasses. The average annual temperature is $11.5^{\circ} \mathrm{C}$ and average yearly rainfall is $412.7 \mathrm{~mm}$ (Baghche Kord Mahale 1999.a).

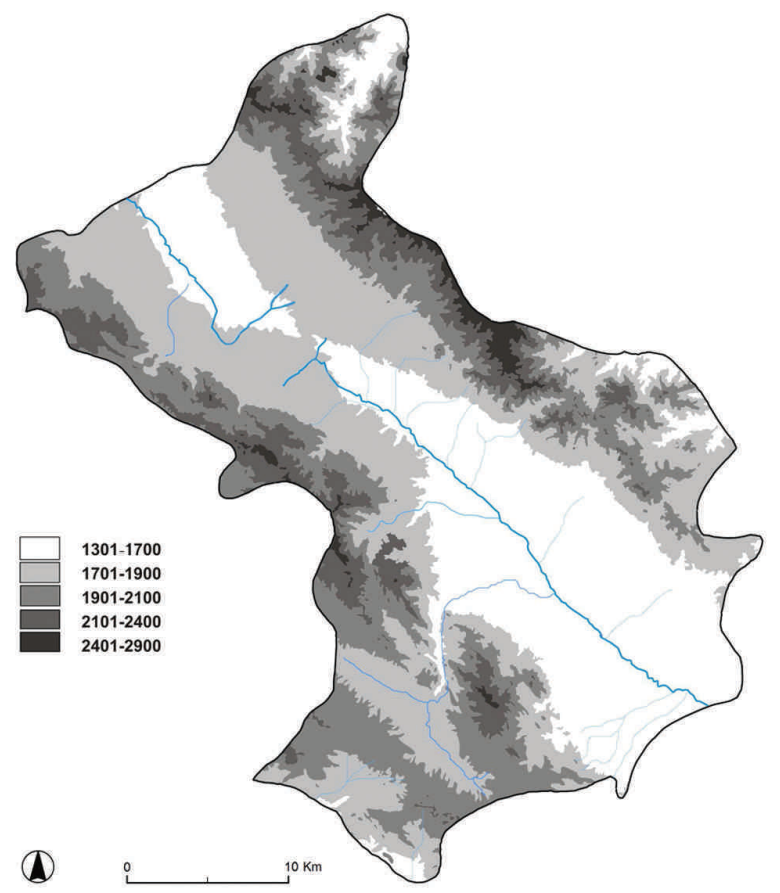

Map 2. The Abharroud valley. 


\section{Archaeological remains}

The two survey seasons led to the identification of 257 sites, which are very variable and remarkable in terms of type, appearance, temporal and spatial distribution. These include: Tapeh or tells, open sites, castles, towns, caves, baths, aqueducts, shrines and other religious sites. During the two seasons, 34 prehistoric sites were discovered in an area of $3400 \mathrm{~km}^{2}$. These include one Lower Palaeolithic site, one Neolithic site, 25 Chalcolithic sites, and 7 possible Bronze Age sites. The prehistoric sites were identified in tell sites and plains (Figs. 1-2), but studies of several caves and rock shelters did not produce any evidence of prehistoric settlement.

\section{The Palaeolithic period}

The earliest evidence of human settlement in the Abharroud basin goes back to the Lower Palaeolithic period. The only site identified (Tapeh Khaleseh) is located near the town of Khoram Dareh (Map 3). Tapeh Khalese includes the remains of a small settlement located within the gardens south of Khoram Darreh and on the terrace of an old drained river. Most surface remains in Tapeh Khaleseh date back to the Neolithic period. During the first season of the survey, and also as a result of several visits to the site between 2003 and 2007, a collection of chipped stones was discovered from the disturbed layers of the site and at a depth of about $2.5 \mathrm{~m}$ lower than the surrounding lands. This collection, which is probably Lower Palaeolithic, includes axes, cores, core-choppers, hammer-stones, flakes, one heavy-duty scraper and one cleaver-like tool (Fig. 3; Pl. 1) (Alibaigi 2009; Alibaigi, Khosravi 2009; Alibaigi et al. 2010).

\section{The Neolithic period}

Most of the material indicating the Neolithic period consists of several types of pottery from Tapeh Khaleseh, which includes red or buff potsherds with thick clay slips in orange, cream, brown and buff colours. Most of the potsherds are coarse, soft and chaff-tempered. All the pottery is hand-made, but fired at different temperatures. Both basket and slab techniques were used to make the vessels. Although some of the ceramics have been fired sufficiently, their surface tends to be multicoloured as the result of using open kilns. Most of the ceramics are open vessels, but closed rims are also visible. There are some interesting samples with rectangular rims; of these we can mention small bowls and small jars. Some pottery is painted with red, black or dark brown coloured geometric and plant motifs such as zigzags, hatched triangles, ladder-like patterns and

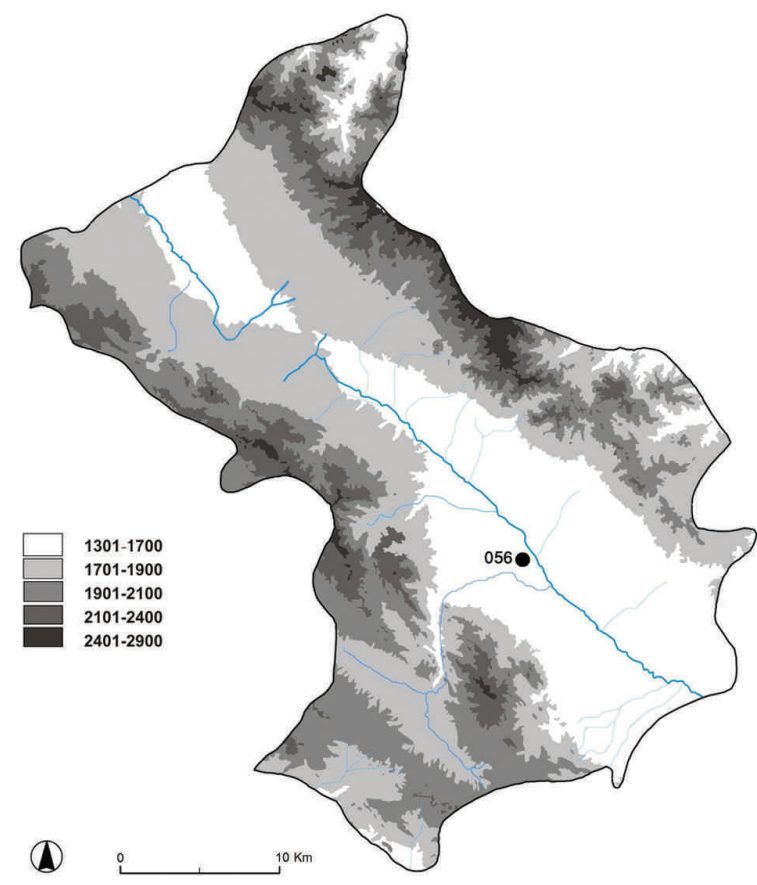

Map 3. The Khaleseh (AB. 056) in Abharroud valley. Location of the Paleolithic and Neolithic sites.

assemblages of wheat or flowers. Both the exterior and interior surfaces are painted, but the paints are applied mainly to the shoulder and base parts of the pottery. Most vessels have carination in the upper part and their forms often include small and large bowls, jars, crocks and large vessels with inverted rims (Fig. 4; Pl. 2). Some of them also have basket handles. The close similarity can be seen between the pottery of this site and other Neolithic sites like Haji Firuz in northwestern and Charboneh and Maay Tepe in Iranian central plateau (Rezaei Kalaj et al. 2010; Voigt 1983; Fazeli Nashli 2007). The investigation of several prehistoric settlements in the Abharroud basin suggests that Tapeh Khaleseh is probably the earliest permanent settlement in the region (Alibaigi, Khosravi 2007).

\section{The Chalcolithic period}

The lack of scientific excavations of the prehistoric sites in the Abharroud basin and the lack of stratigraphic information make it difficult to sub-divide the Chalcolithic period in the region. However, excavations at sites such as Tapeh Ghabrestan (Majidzadeh 1977; Madjidzadeh 2008; Fazeli Nashli 2006), Ozbaki (Majidzadeh n.d.; 2004; 2010), Esmail Abad (Fazeli Nashli, Ajorlou 2006), Tapeh Shizar (Valipour 2006) and Soha Chai Tapeh (Aali 2008) have provided valuable information about the Chalcolithic and Bronze Age cultures on the northwestern outskirts of the central plateau of Iran and Zanjan province. 
As result of the survey, 25 Chalcolithic sites were identified. Other than settlement sites, another Chalcolithic site, Chakhmagh Dasheh, was discovered that had different occupational features. The surface material such as various cores and flakes and other unused tools indicate that the site, located on a mountainside, was probably a workshop producing chipped stones.

The Chalcolithic pottery from the region consists of sherds with red, orange, grey and smoked paste. The exterior surfaces are covered with dark red (early Chalcolithic phase), red or grey (middle Chalcolithic phase), and reddish orange or light grey (late Chalcolithic phase) slips. This pottery is all hand-made and fired at low temperatures; therefore the cores are smoked. Some potsherds are decorated with rather plain geometric patterns, and in a few cases with motifs of animals painted in dark colours. The vessels are rather plain in form and include small and large bowls, vessels with vertical bodies and plain rims, crocks and storage jars (Figs. 5-16; Pls. 3-8). Furthermore, during the survey of other sites such as Kharabeh I, Guy Sadeh, Falj, Chakhmaghlukh, Qieh, Karvansara, Shahrbanoo and many others, potsherds from the middle and late Chalcolithic periods were discovered, which are contemporary with settlements in the central Zagros like Godin Tepe (Cuyler Young, Levine 1974; Henrickson 1983), Dalma Tepe and Tepe Sivan in northwestern Iran (Hamlin 1975; Soleki, Soleki 1975) and Tepe Ghabristan and Tepe Ozbaki in Iranian central plateau (Madjidzadeh 2008; 2010).

The number of sites relating to this period indicates remarkable growth in population and settlements compared to previous periods. The sites in this period were scattered both on the plains and in the highlands. The southern heights and mountainsides of the basin host 10 sites; 8 sites are located in the northern heights and mountainsides and 7 are located on the plain, close to the Abhar river. The highest site lies $2150 \mathrm{~m}$ above sea level, while the lowest is $1490 \mathrm{~m}$ above sea level (Map. 4). The Chalcolithic settlements are usually located less than $200 \mathrm{~m}$ from the nearest water sources.

\section{The Bronze Age}

A total of 7 Bronze Age sites were identified. Of these, two (AB. 055 and 189) had been occupied during the Chalcolithic period and continued into the Bronze Age; the remainder were new sites. Such a change in the number of sites indicates a relative shift in settlement patterns in the Bronze Age com- pared to the preceding periods. The cultural material from tell and open-air sites generally consists of grey-black and red-coloured potsherds that are typical for the Bronze Age in the west and northwest and for the late Bronze Age in the centre of the Iranian plateau.

The early Bronze Age material is marked by grey-coloured pottery (the so-called Yanik style). These vessels are all hand-made, mineral-tempered and fired at low temperatures. The pottery occurs in the form of small and large bowls and straight-walled vessels. In addition to these, several potsherds with orange slip were found at these sites (Fig. 17; Pl. 9). These vessels are also hand-made and rather coarse.

During the survey of Qaleh Tapeh in Abhar, in addition to the early Bronze Age potsherds (Yanik style), some late Bronze Age (the so-called Sagz Abad style) potsherds were found which are consistent with the pottery tradition of the late Bronze Age in the central plateau (Sagz Abad, Qoli Darvish). This handmade and coarse pottery is characterized by sand inclusions, is coloured from buff to red paint, and the vessel surface was decorated by irregular black and red bands (Masoumi 2008).

Chalcolithic and Bronze Age potsherds were found together at two sites. Generally speaking, the Bronze Age sites of the area are related to the Yanik culture known in northwestern and western Iran. For example, Yanik pottery was found on two sites: Qaleh Ta-

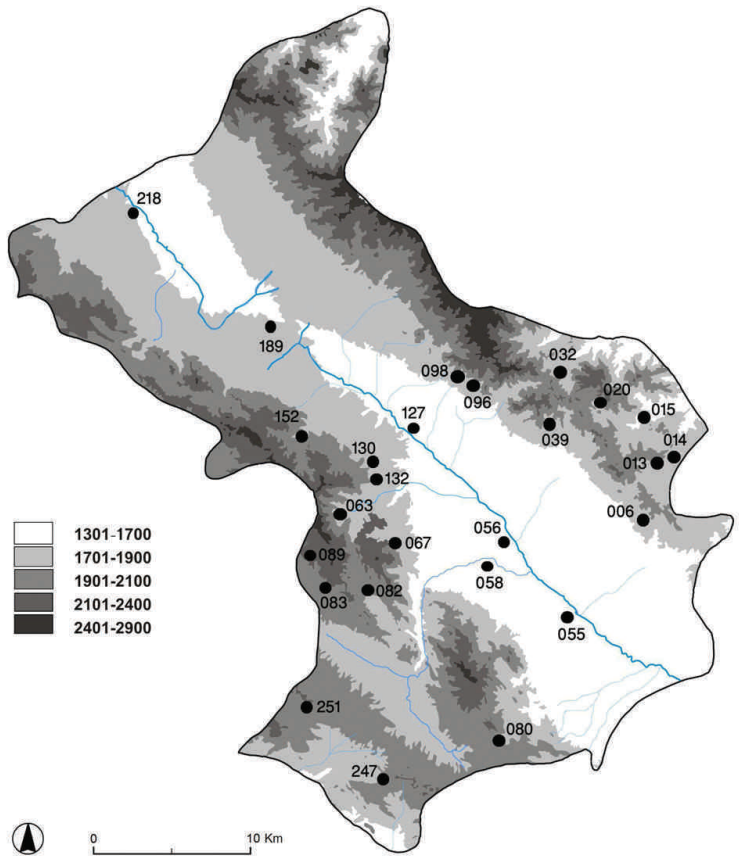

Map 4. The Abharroud basin; the distribution of Chalcolithic settlements. 
peh and Aliyord Tapehsi (Khosravi 2009; Asgarian 2001). All Bronze Age sites are located in the southern areas of the basin while there are absent in the northern part. Like in the Chalcolithic period, the sites are scattered in both the plain and the highlands (1497 to $1972 \mathrm{~m}$ above sea level) (Map 5). There is a drastic reduction in the number of settlements compared to previous periods (only Qaleh Tapeh was settled continuously from the Chalcolithic to the Bronze Age).

\section{Conclusions}

The two seasons of archaeological surveys in the Abharroud basin produced valuable information on the cultures of various periods in the region, especially in prehistory. The survey results provided significant evidence on relations between the prehistoric cultures of the region and contemporaneous cultures in the central plateau and western and northwestern Iran. Lack of sufficient information and scientific excavations in the basin compels us to date the sites on the basis of a typological comparison between the finds of this region and those of contemporary cultures in neighbouring areas. According to our studies, the data obtained from surveying the prehistoric sites reveal evidence of a period of occupation between the Palaeolithic and the end of the Bronze Age (Map 6).

The settlement distribution shows that the only Neolithic site in the region, Khaleseh, is located in the centre of the plain and on the bank of the Abhar river. As the areas around the river have been ploughed, it is possible that small Neolithic sites have been destroyed. Furthermore, it is also probable that the remains of this period are buried under natural sediment or under the remains of the Chalcolithic or more recent periods.

All of the Neolithic and later sites, except for the single Chalcolithic site (Chakhmagh Dasheh AB. 132) were probably settlement sites and villages of varying sizes, scattered over a vast area of the region. In general, prehistoric settlements can be found in many areas of the basin. Early settlements are relatively rare in the high mountains and the areas between the Abharroud river and northern mountains. Cold weather, rocky terrain and the absence of permanent water sources seem to be the main reasons for this rarity. Prehistoric settlements, especially those of the Chalcolithic period, are usually located on mountainsides. Permanent springs played a signi- ficant role in the development of these settlements in the northern mountains.

Geographical features undoubtedly had a decisive influence on the development and distribution of settlements. All the identified sites, except for Chakhmagh Dasheh (AB. 132), were probably villages and/ or seasonal camps of various sizes, which developed near permanent water sources such as springs and rivers, many of which still have water and are being exploited today. A few sites are located near streams and drained channels. Like today, rocky terrain and areas without permanent water sources were rather neglected.

As mentioned above, Chalcolithic sites are more frequent in the southern areas of the basin than in the northern parts. This may be due to the difference between the environmental conditions of the two areas. The land between the Abharroud river and its northern mountain has a pebbly soil and lack of permanent rivers. In contrary, the southern part of the Abharroud basin has a more fertile land accompanied by permanent rivers and springs. Most of these sites are small settlements whose dwellers seem to have lived on cultivation, hunting and animal husbandry. Considering that some of these settlements are located at elevations above over $1700 \mathrm{~m}$ and taking into account the fact that the region is very cold in autumn and winter, it is very probable that the highland settlements belonged to nomadic people.

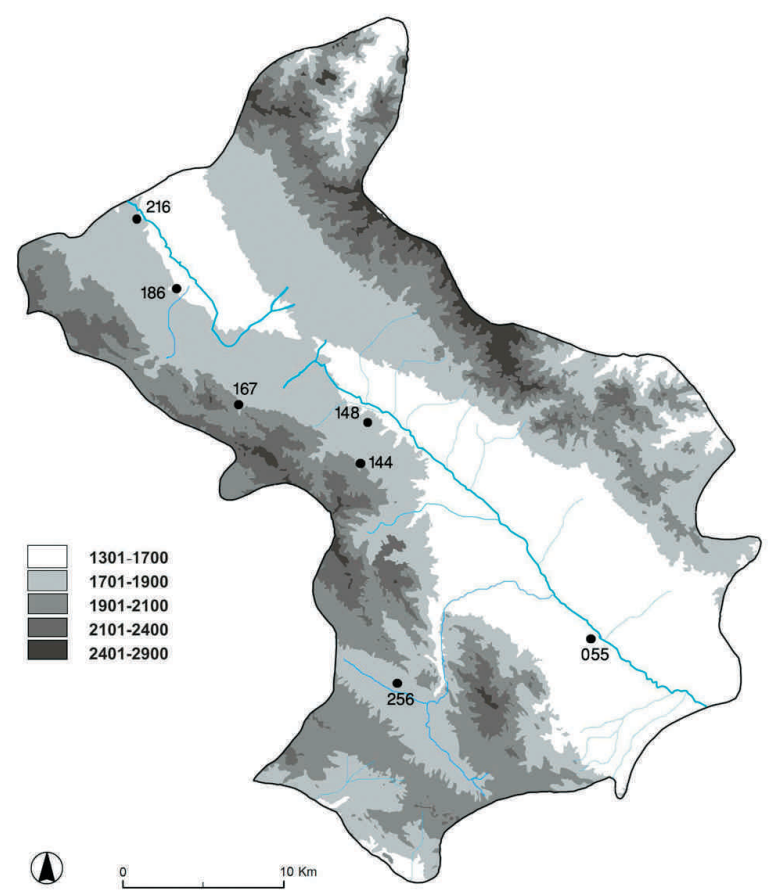

Map 5. The Abharroud basin; the distribution of the Bronze Age settlements. 


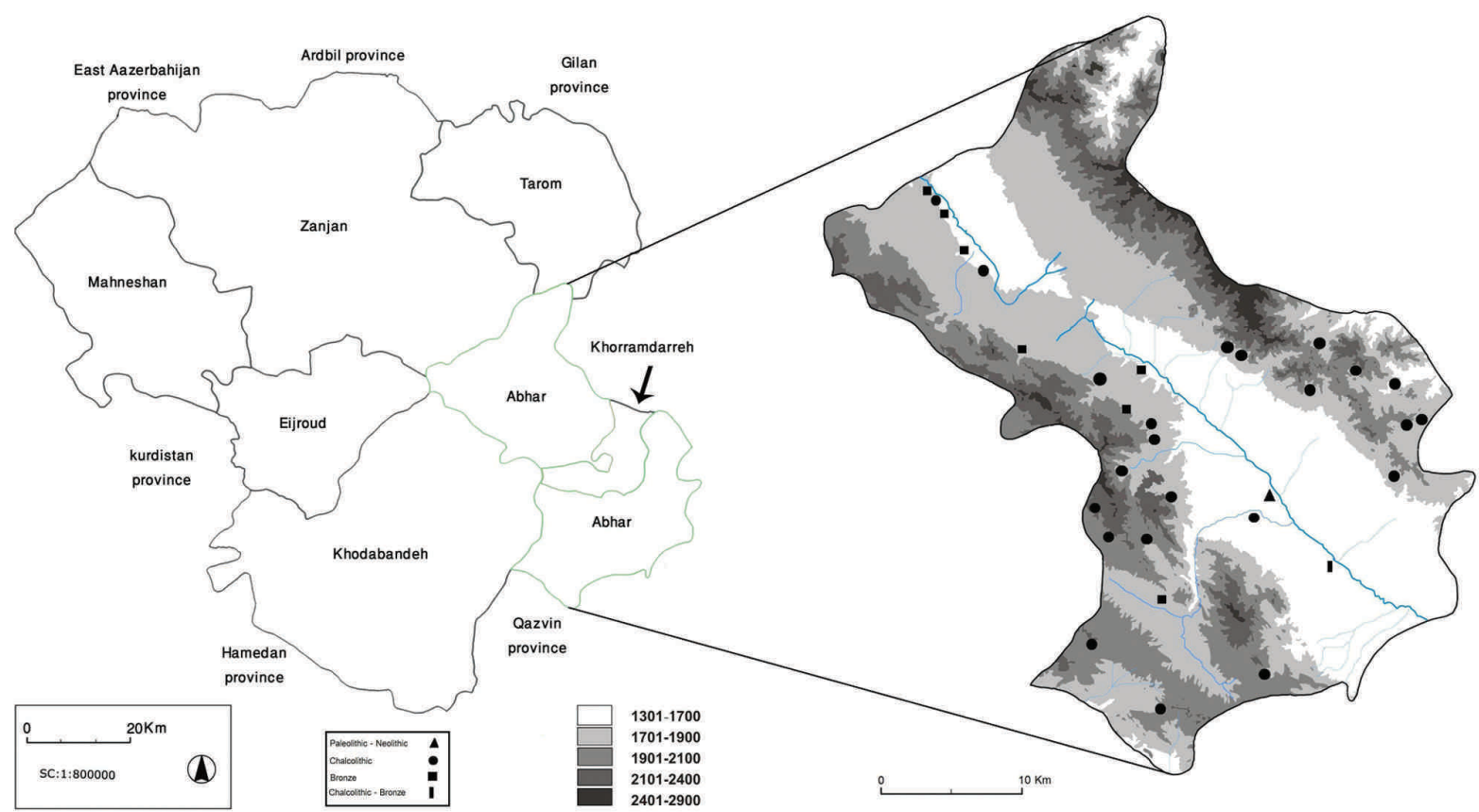

Map 6. The Abharroud basin; the distribution of prehistoric sites.

The finds generally suggest the influence of cultures known in neighbouring areas and cultural contact with contemporary prehistoric cultures in the northwest, west and centre of the Iranian plateau.

We should restate that, due to the fact that most of the areas around the Abharroud are now farms and gardens, it is probable that early settlement sites which usually developed in lowlands and over small areas - have disappeared. Unfortunately, as in many other regions in Iran, most of the ancient sites in the basin have been destroyed by human activity and illegal excavations. Neglecting such damage may give rise to unwelcome errors when presenting settlement patterns. Therefore, these problems must be taken into consideration when establishing regional chronologies, settlement patterns, and rank-size graphs of different periods.

$$
\text { ACKNOWLEDGEMENTS }
$$

The authors are grateful to all members of the survey, who tirelessly contributed the team achieving its research goals. We should also express our appreciation to Fereidoun Biglari for his valuable guidance in the study of chipped stone finds. Thanks to Mojtaba Charmchian, Mehrab Hemati, Sirvan Mohammadi Qasrian and Zahra Ghaffari for their contributions. We are also grateful to Dr. Hoijat Darabi for reviewing this paper.

\section{References}

Aali A. 2004a. A Report on the First Season of the Archaeological Survey and Identification of Abharrud Basin (Abhar and Khorram Darreh county). Unpublished report in Archive of the Cultural Heritage Organization of Zanjan Province. (in Persian)

2004b. A Report on the Survey and Identification of Khorram Darreh County. Unpublished report in Archive of the Cultural Heritage Organization of Zanjan Province. (in Persian) 2006a. A Report on the Second Season of the Archaeological Survey and Identification of Abharrud Basin (Abhar and Khorram Darreh County). Unpublished report in Archive of the Cultural Heritage Organization of Zanjan Province. (in Persian)

2006b. A Descriptive Report on the Archaeological Survey and Identification of Abharrud Basin, Payam-e Bastanshenas. Archeological Journal of Islamic Azad University of Abhar 3(6): 17-42. 
2008. Salvage excavations in Golabar dam basin. Unpublished report in Archive of the Cultural Heritage Organization of Zanjan Province. (in Persian)

Alibaigi S. 2009. The first evidence from Lower Palaeolithic period in the Khorram Darreh valley, in northwestern borders of Iranian Central Plateau. Unpublished MA thesis, Department of Archaeology, University of Tehran. Iran. (in Persian)

Alibaigi S. and Khosravi Sh. 2007. Tepe Khaleseh: Earliest Prehistoric Settlement in Abharrud Basin. Bastan Pazuhi 15: 35-47.

2009. Tepeh Khaleseh: a new Neolithic and Palaeolithic site in the Abharrud basin in north-western Iran. Antiquity 83(319), Project Gallery.

in press. Prehistoric Archaeology of Zanjan province. In Y. Hassanzadeh, S. Miri (eds.), Proceedings of the symposium of 80 years of Iranian Archaeology. Tehran, National museum of Iran. (in Persian)

Alibaigi S., Niknami K. and Khosravi Sh. 2010. A Preliminary Report on the Investigations of the Lower Paleolithic site of Khaleseh in the Khoram Dareh Valley, Zanjan. Iranian Archaeology 1(1): 8-14.

Alibaigi S., Niknami K., Khosravi Sh., Charmchian M. and Hemmati M. 2011. An Impressed Pottery Sherd: A Chalcolithic Newfound in the Southern Highland of Abharroud river basin. Iranian Journal of Archaeological Studies 1: 44-54.

Alibaigi S., Niknami K. and Khosravi Sh. in press. Khaleseh: The first evidence from the Lower Paleolithic occupation in Khorram Dareh Vally, North - Western borders of Iranian Central Plateau. In F. Biglari, M. Mashkour., S. Shidrang and K. Abdi (eds.), Paleolithic of Zagros and Iranian plateau, Recent Research and Re-analysis. Studies in early near Eastern production, subsistence, and environment, Ex Oriente, Berlin.

Asgarian M. 2001. Report of sounding at Qaleh Tape Abhar. Unpublished report in Archive of the Cultural Heritage Organization of Zanjan Province. (in Persian)

Baghcheh Kord Mahaleh A. 1999. Geomorphology of $A b$ harroud Basin and environmental management. Unpublished MA thesis. Department of Geography, University of Tehran. Iran. (in Persian)

Cuyler Young T. Jr., L. D. Levine 1974. Excavation at Godin Tepe; Secound Progress Report. Occasional Paper 26, Art and Archaeology. Royal Ontario Museum, Ontario.
Fazeli Nashli H. 2006. The Archaeology of the Qazvin plain from the sixth to first millennium B.C. Tehran University press. Tehran. (in Persian)

Fazeli Nashli H., Ajorloo B. 2006. Tapeh Esmaeil Abad. In H. Fazeli Nashli (ed.), The Archaeology of the Qazvin plain from the sixth to first millennium B.C. Tehran University press, Tehran: 148-209. (in Persian)

Fazeli Nashli H., Ilkhani H., Marghusian A. and Beshkani A. 2007. A Preliminary Report on Sounding and Stratigraphy of Tepe Chahar Boneh of Ghazvin Plain. Archeological Reports (7) on the Occasion of The 9th Annual symposium on Iranian Archaeology (1st Volume), Research Center For ICHHTO, Iranian Center For Archaeological Research, Tehran: 355-376.

Ganjavi S. 1975. Dash kasan Shirin and Farhad. Barresihay Tarikhi 10: 25-34. (in Persian)

1976a. Excavation at Nour Tepeh in Historical city of Soltanieh. Barresihay Tarikhi 11: 161-196. (in Persian)

1976b. Survey and organic excavation in Soltanieh. In F. Bagherzadeh (ed.), Proceedings of the $4^{\text {th }}$ annual symposium on archaeological research in Iran. Iranian Centre for Archaeological Research, Tehran: 7491. (in Persian)

Hamlin C. 1975. Dalma Tepe. Iran XIII: 111-128.

Henrickson E. 1983. Ceramic styles and cultural interaction in the early and middle Chalcolithic of the central Zagros, Iran. Unpublished PhD thesis. Department of Anthropology. University of Toronto. Toronto, Canada.

Kazempour Esmati P. 2009. Report of the fourth season of excavation at Nour Tapeh (Prehistoric). Unpublished report in Archive of the Cultural Heritage Organization of Zanjan Province. (in Persian)

Khosravi Sh. 2009. Prehistoric settlement patterns in Abharroud basin. Unpublished MA thesis. Department of Archaeology. University of Tarbiat Modares. Tehran. (in Persian)

Khosravi Sh. and Alibaigi S. 2008. Prehistoric settlement in Abharroud Basin, on the north-western borders of Iranian central plateau. In $2^{\text {nd }}$ International Congress of society of south Asian Archaeology. Shiraz, Iran, May 2008, Abstract Book, Shiraz: 43. (in Persian)

in press. Shahrbanou: Some Evidence on Chalcolithic Occupation in the heights of the Abharrud Basin. Iranian Archaeology 2. (in Persian) 
Khosravi Sh., Khatib Shahidi H. and Alibaigi S. 2009. Abharrud basin in Chalcolithic period: Revision to the Dalma settlements at the north-western borders of the Iranian central plateau, Payam-e Bastanshenas. Archeological Journal of Islamic Azad University of Abhar 12: 37-52. (in Persian)

Khosravi Sh., Khatib Shahidi H., Vahdatinasab H. and Alibaigi S. 2010. Prehistoric settlement patterns in Abharroud basin, Payam-e Bastanshenas. Archeological Journal of Islamic Azad University of Abhar 13: 23-46. (in Persian)

Majidzadeh Y. 1977. Excavation at Tapeh Ghabristan of Sagzabad. Marlik 2: 53-71. (in Persian)

2004. Report of the third season of excavations at ancient site of Ozbaki. Research centre for ICHHTO, Iranian Centre for Archaeological Research, Tehran. (in Persian)

2008. Excavation at Tepe Ghabristan. Reports and memoirs, new ser., vol. 7. Istituto italiano per l'Africa e l'Oriente. Roma.

2010. Excavations at the ancient site of Ozbaki, Vol. 2: Pottery. Research centre for ICHHTO. Tehran. (in Persian)

n.d. The first and second season of archaeological excavations at site of Ozbaki, Savojbolaq. 1998, 1999, ICHO. Tehran. (in Persian)

Masoumi 0. 2008. Evidences of Settlements of early Chalcolithic period and Iron Age in Tepeh Qaleh of Abhar. Parsehgard 7: 1-12. (in Persian)
Rezaei Kalaj M. R., Davoudi H. and Sadeghi E. 2010. Report of Salvage excavations in at late Neolithic site of May Tapeh, Qazvin plain, Payam-e Bastanshenas. Archeological Journal of Islamic Azad University of Abhar 13: 123. (in Persian)

Sazman-e Amozesh va Parvaresh ostan-e Zanjan 1996. Geography of Zanjan Province. Sazman-e Amozesh va Parvaresh ostan-e Zanjan. Zanjan. (in Persian)

Sazman-e Modiriat va barnamehrizi ostan-e Zanjan 2004. Basic statistics of Zanjan Province. Shoray-e tahghighate Sazman-e Modiriat va barnamehrizi ostan-e Zanjan. Zanjan. (in Persian)

Soleki R., Soleki R. 1975. Tepe Sivan, A Dalma period site in the Margavar valley Azerbaijan, Iran. Bulletin of the Asian Institute 3: 98-116.

Valipour H. 2006. Report of thefirst season of archaeological excavation at Shizar. Unpublished report in Archive of the Cultural Heritage Organization of Qazvin Province. (in Persian)

Valipour H., Davoudi H., Mostafapour I. and Gerzak A. in press. Tepe Khaleseh a late Neolithic site in Zanjan province, preliminary report on the 2009 excavation. In $\mathrm{H}$. Fazeli Nashli, R. Mattews (eds.), Neolithisation of Iran. British Association for Near Eastern Archaeology and Oxbow Books. Oxford.

Voigt M. M. 1983. Hajii Firuz Tepe, Iran: the Neolithic settlement. University museum Monograph 50, University of Pennsylvania. Philadelphia. 


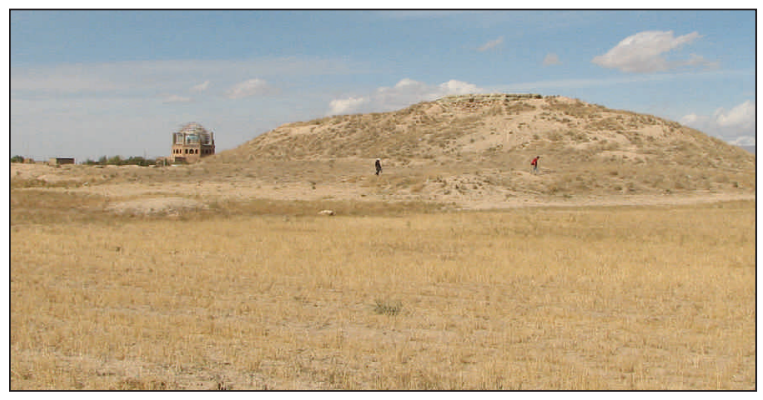

Fig. 1. A view of Nour Tapeh (AB.189); a large Dalma settlement near Sultanieh.

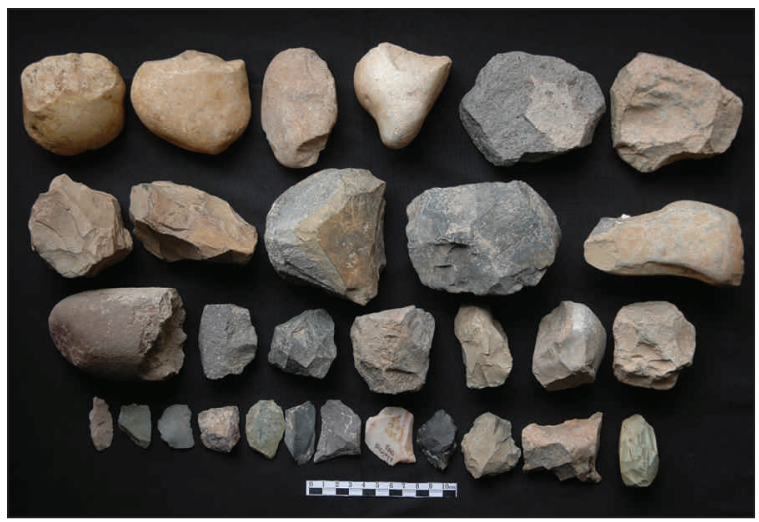

Fig. 3. The Khaleseh site; a possible Lower Palaeolithic stone tool assemblage.

Fig. 5. A Dalma painted pottery found at Nour Tape, Sultanieh in 2002 (courtesy of the Archaeological Museum of Zanjan).

Fig. 7. The Algezir Chay site (AB. 152); the Chalcolithic painted pottery.

Fig. 9. The Shahrbanou site (AB. 013); Dalma painted pottery with the representation of goats with long horns.
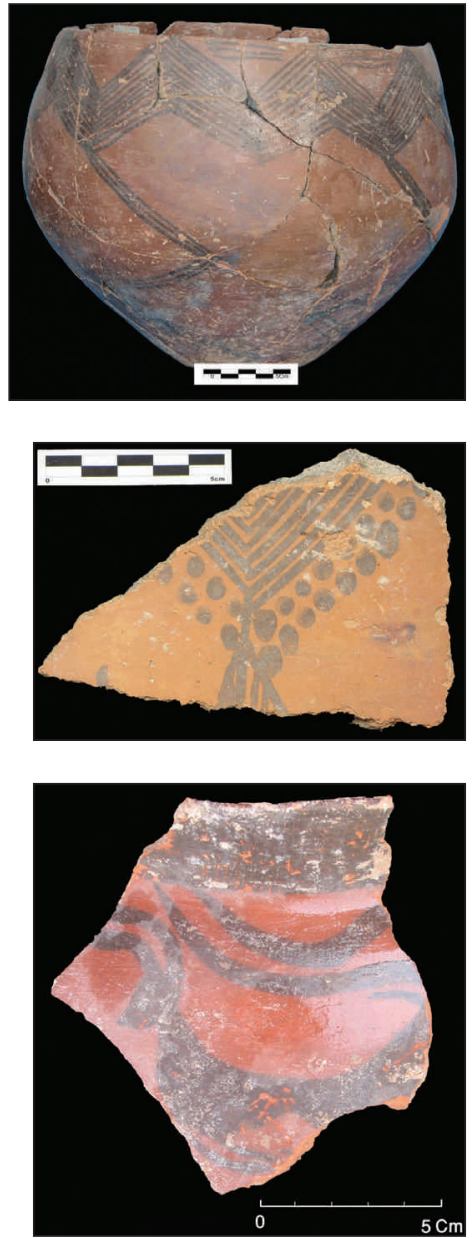

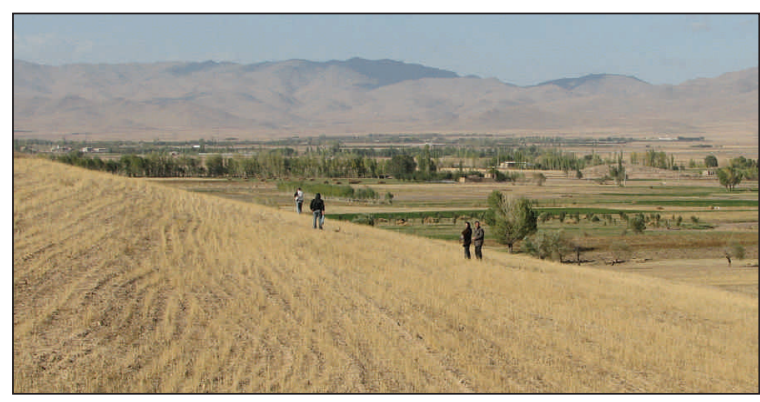

Fig. 2. A view of Burokh Tapeh (AB.218); a Dalma settlement near Sultanieh.

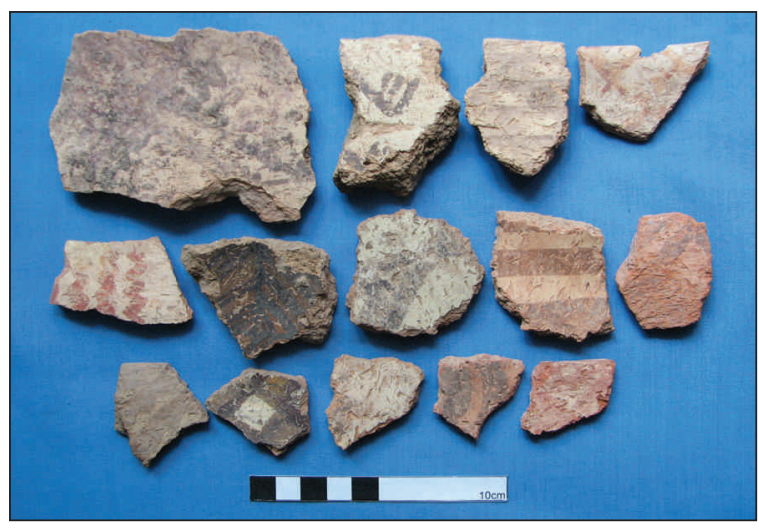

Fig. 4. The Khaleseh Tepeh (AB. 056); the Neolithic painted pottery.

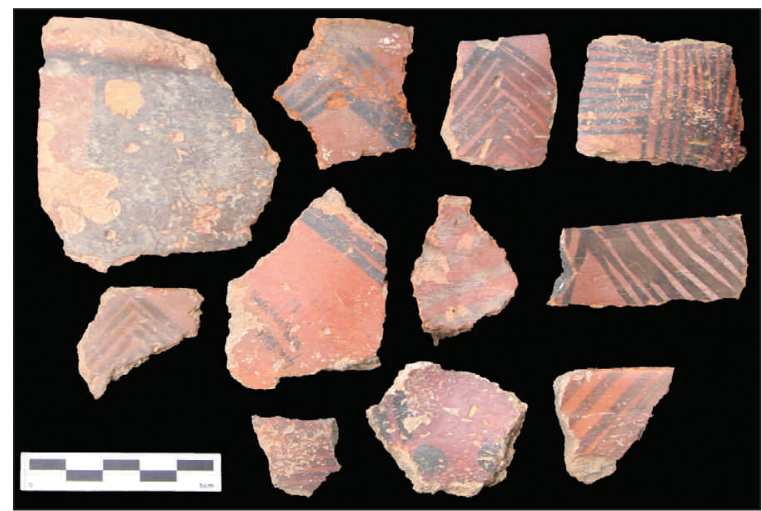

Fig. 6. The Karvansara site (AB. 014); the Dalma painted pottery.

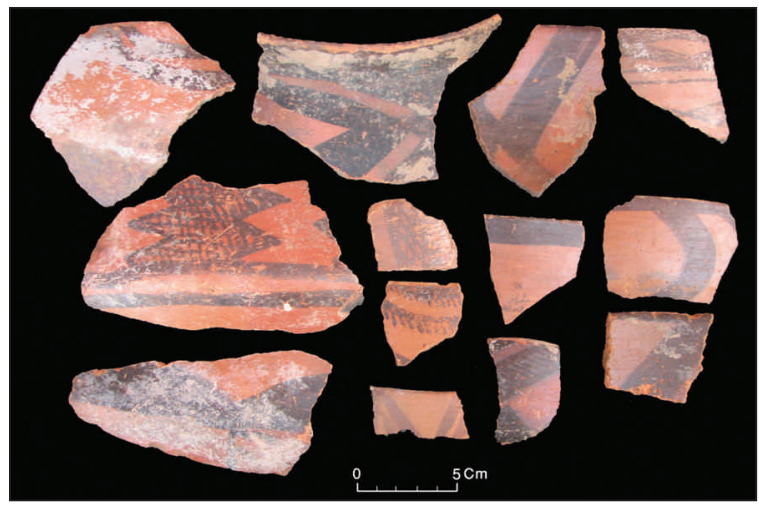

Fig. 8. The Shahrbanou site (AB. 013); the Chalcolithic painted pottery. 


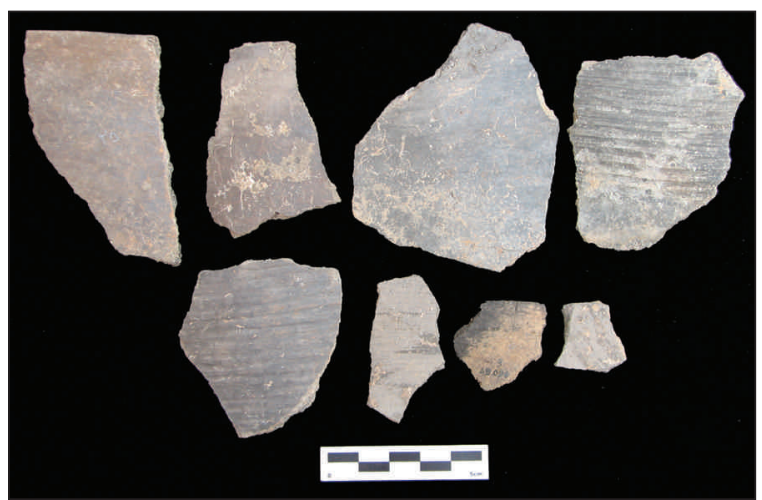

Fig. 10. The Khorasanlo site (AB. 096); the Middle Chalcolithic grey carved pottery.

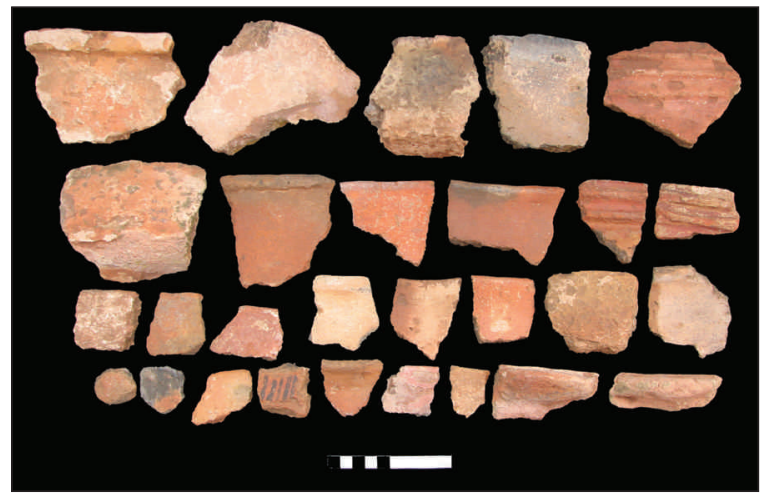

Fig. 12. The Chakhmaqloukh site (AB. 082); the Late Chalcolithic pottery.

Fig. 14. The Chakhmaqloukh site (AB. 082); the Chalcolithic pottery with stamp seal impression.

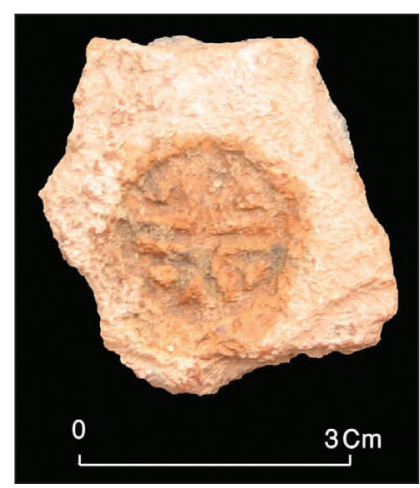

Fig. 15. The Falj site (AB. 067); the Chalcolithic decorative object.

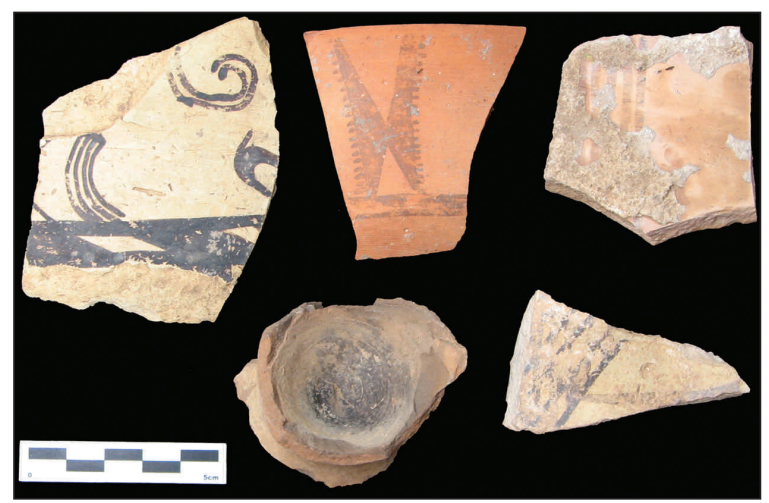

Fig. 11. The Guy Sadeh site (AB. 251); the Chalcolithic painted pottery.

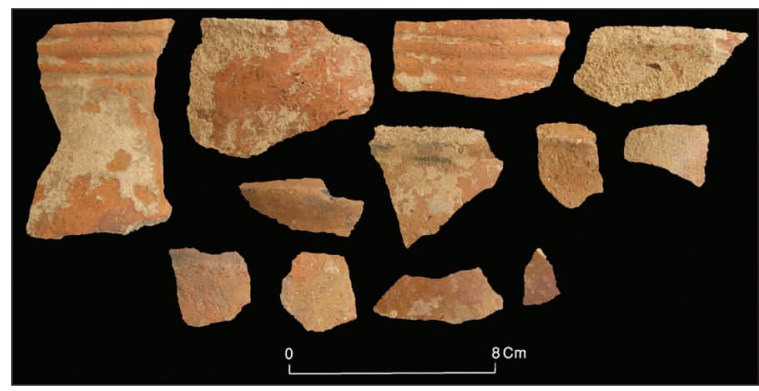

Fig. 13. The Kohneh Ghabrestan Baghdareh site (AB.063); the Late Chalcolithic pottery.

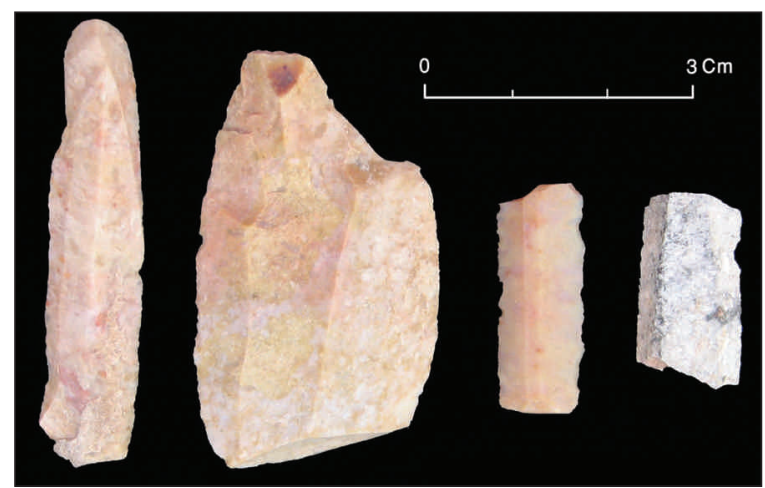

Fig. 16. The Shahrbanou site (AB. 013); the Chalcolithic stone tools.

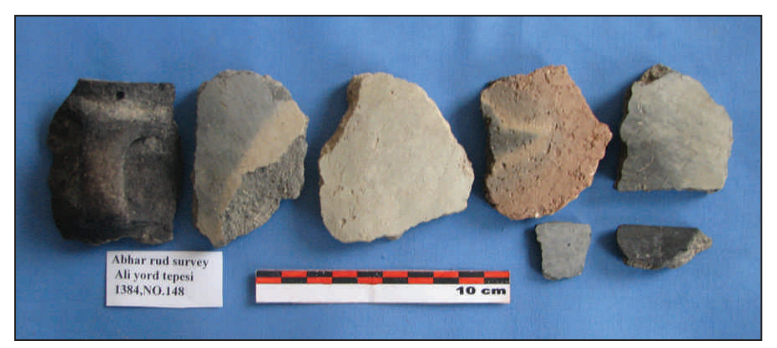

Fig. 17. The Aliyord Tapesi site (AB. 146); the Early Bronze Age pottery. 

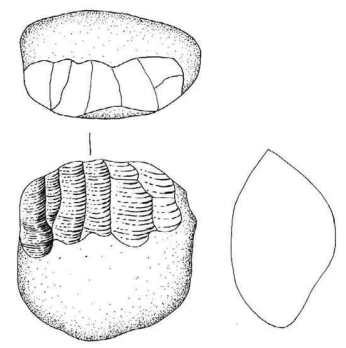

1
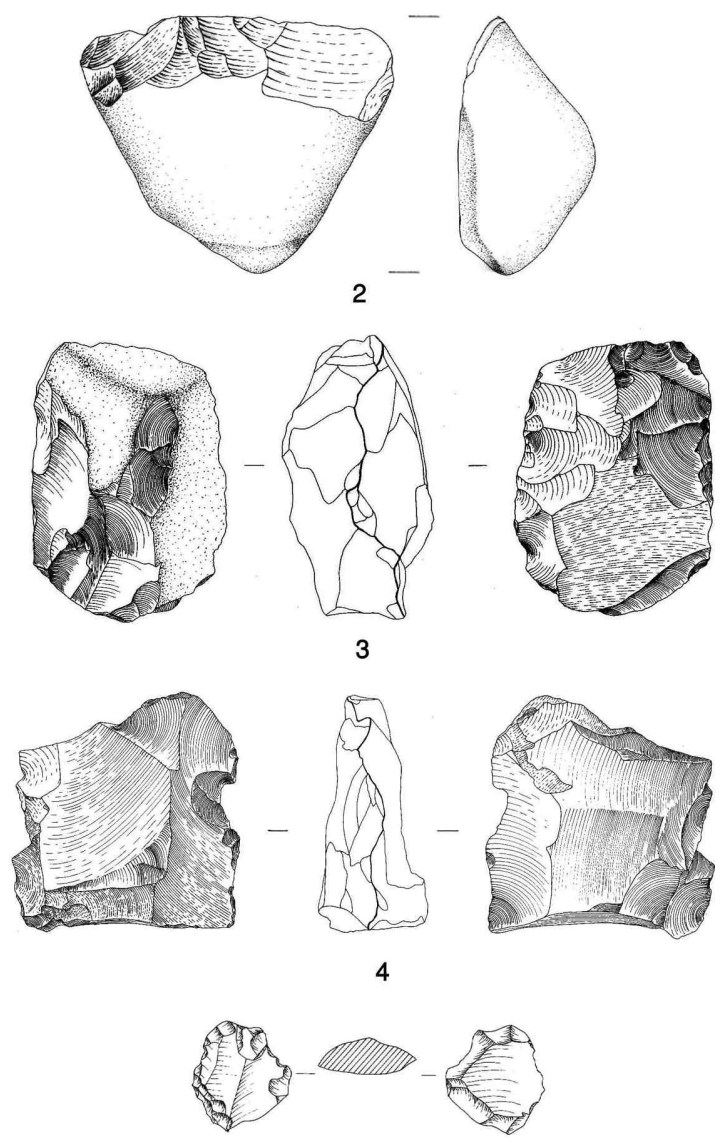

5

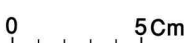

Pl. 1 . The Khaleseh site. 1- 2 choopers, 3 core, 4 large core fragment, 5 retouched flake.

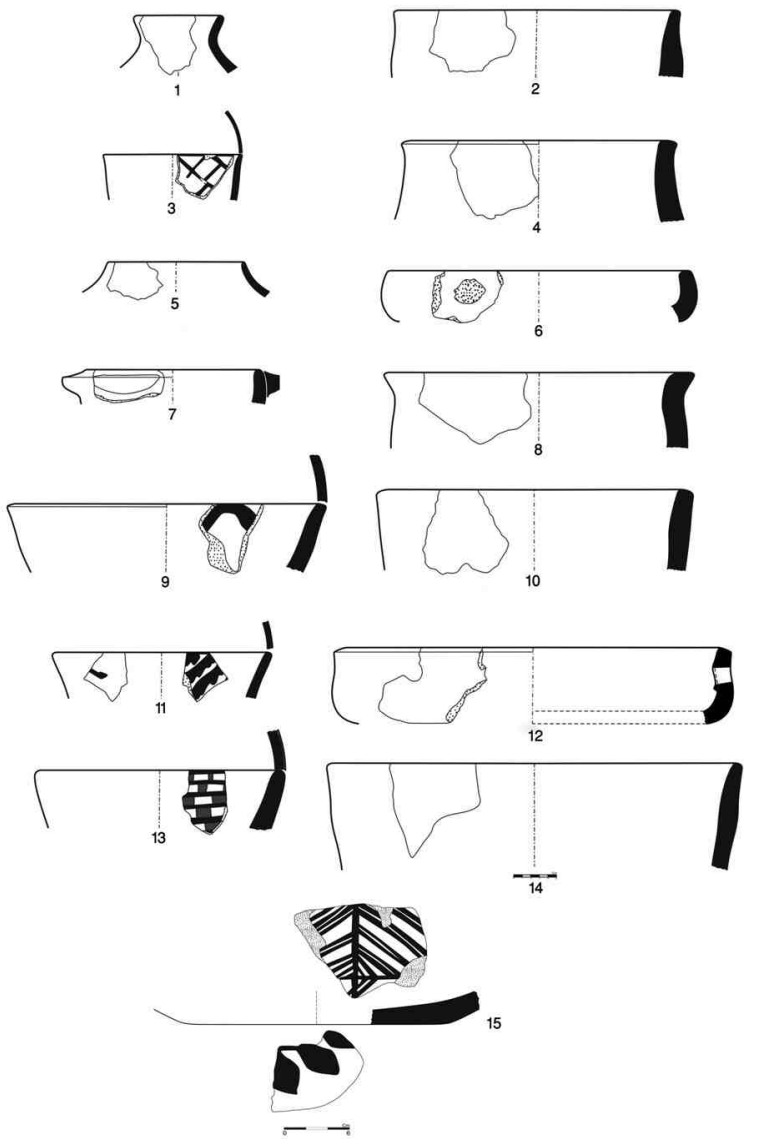

Pl. 2. The Tepeh Khaleseh; the Late Neolithic pottery assemblage.

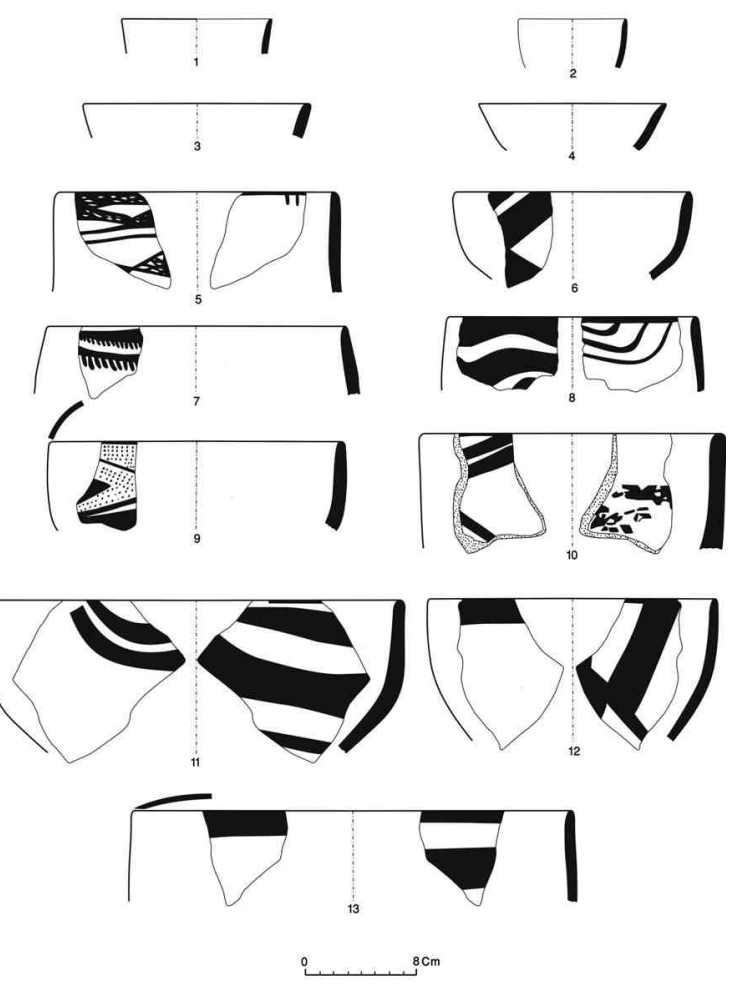

Pl. 3. The Abharroud basin; the Chalcolithic pottery assemblage. 


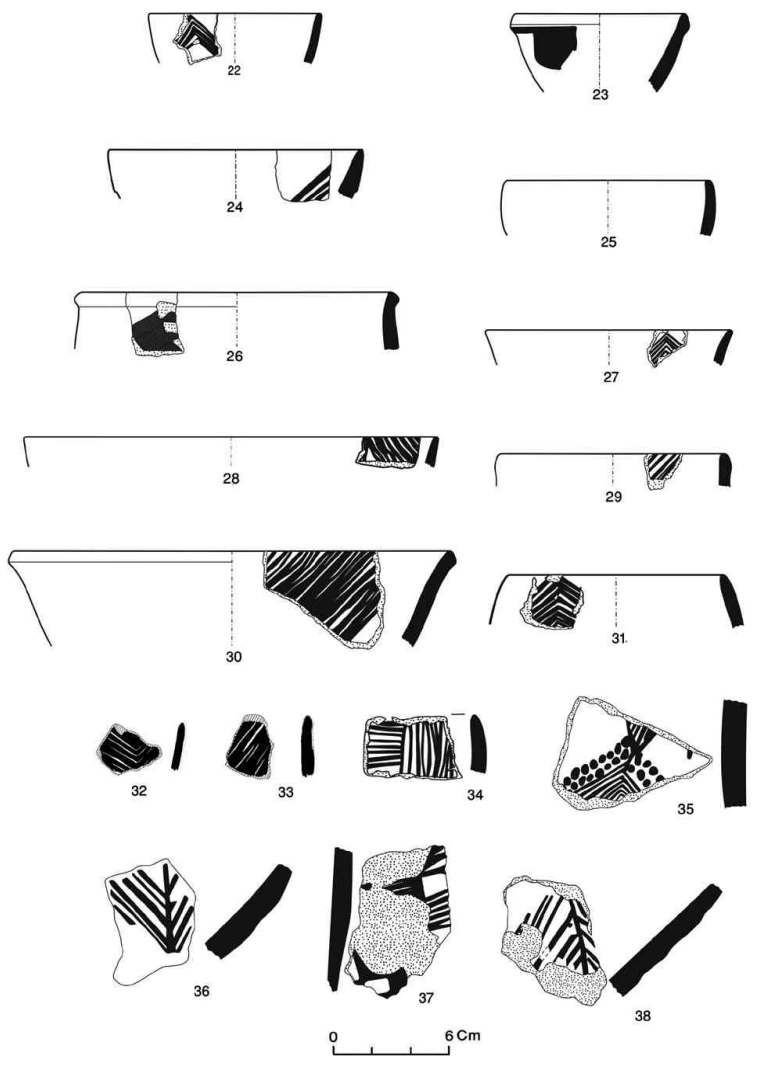

Pl. 4. The Abharroud basin; the Chalcolithic pottery assemblage.
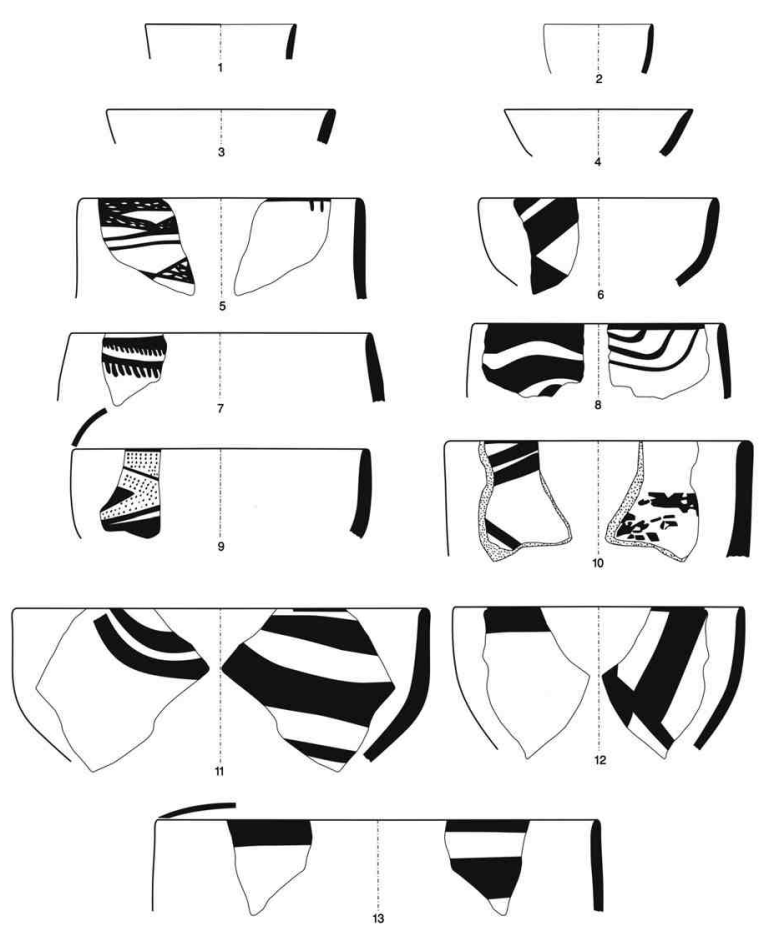

${ }^{8 \mathrm{Cm}}$

Pl. 6. The Abharroud basin; the Chalcolithic pottery assemblage.
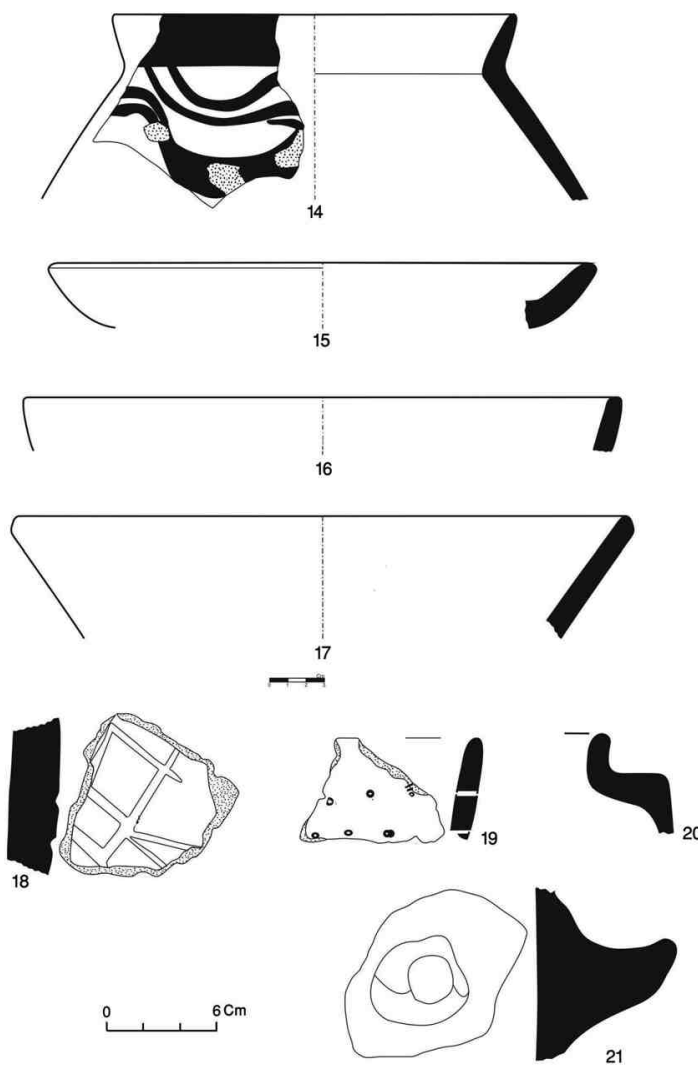

Pl. 5. The Abharroud basin; the Chalcolithic pottery assemblage.

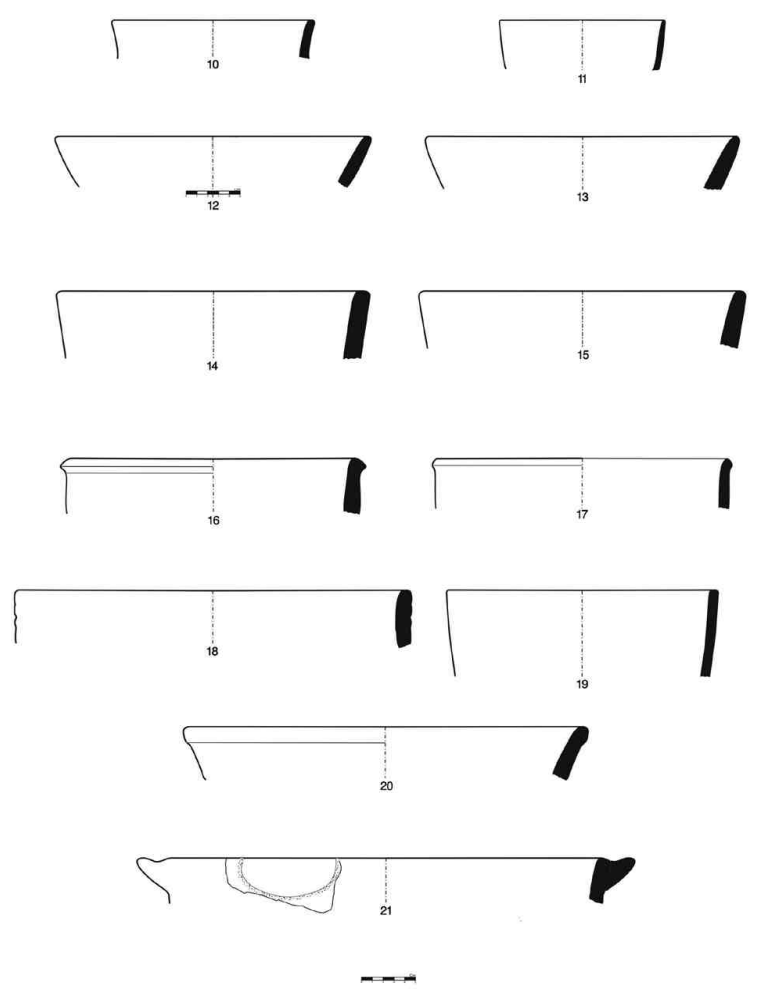

Pl. 7. The Abharroud basin; the Chalcolithic pottery assemblage. 


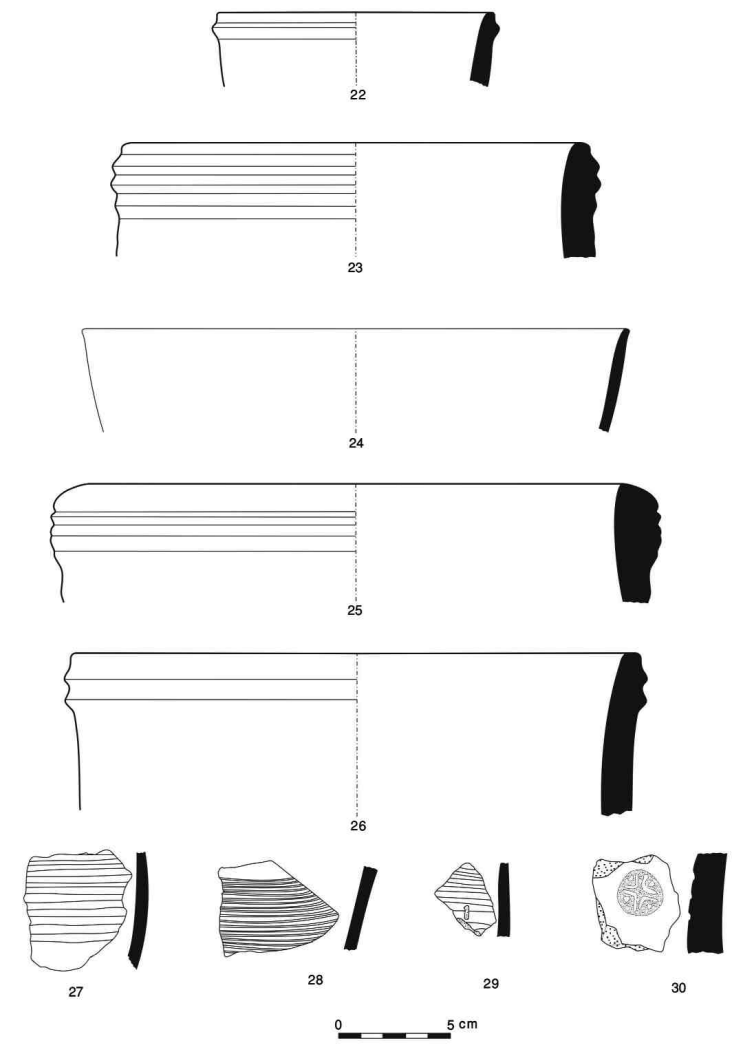

Pl. 8. The Abharroud basin; the Chalcolithic pottery assemblage.

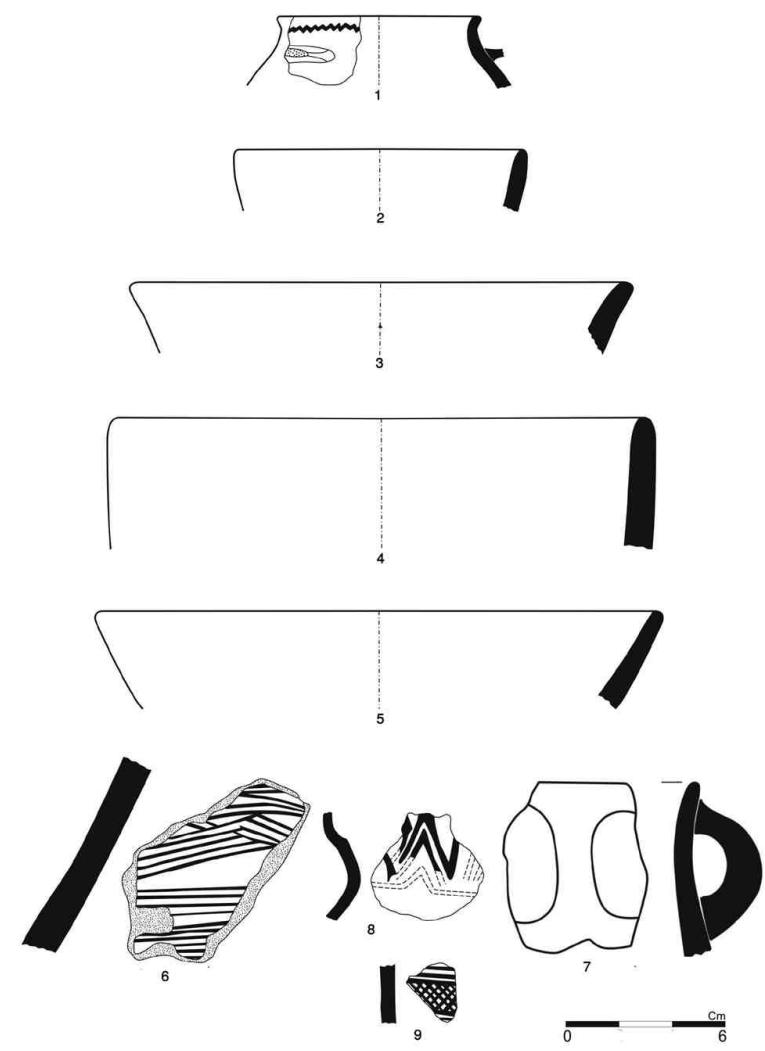

Pl. 9. The Abharroud basin; the Bronze Age pottery assemblage. 